\title{
14
}

\section{Talking Shop: A Comparative Feminist Approach to Caribbean Literature by Women}

\author{
VEVE A. CLARK
}

Rarely do we examine the relationship between feminist theory and practice as the two arenas converge in pedagogy, particularly in undergraduate courses such as one I have offered at both Tufts University and the University of California. In "Developing Diaspora Literacy and Marasa Consciousness," I attempted to chart an innovative theoretical approach to texts beyond the typical dyadic relationships so commonly reproduced in comparative literature studies. ${ }^{1}$ Whether confined to texts produced within and defined by national boundaries, genres, and periods, or to intertextual analyses beyond these periods, the prevalent comparative model has indulged in a restrictive one-on-one paradigm. Ultimately, the process creates a vertical hierarchy, reflecting the critic's preference for one text over the other. The marasa principle, drawn from traditional Haitian lore, suggests at once a pairing of texts for consideration and a commitment to a creative critical process which illuminates a third or wider field of expression beyond binaries. Following the nature-oriented and mystical philosophies from Asia, Africa, and the Caribbean, this particular theory when applied to comparative literature is based on the notion that $1+1=3$.

The marasa sign clarifies the dynamics of social change, the transformation of cultural oppositions within plantation societies. Movement beyond double-consciousness or the binary nightmare of a psyche divided by memory between Africa and Europe occurred particularly in the development of indigenous religious practices (Vodoun, Santería, Shango, Candomblé), Creole languages and mixed-race identities drawn together rather than apart. Coming to marasa consciousness in the late twentieth century means that the structure of analysis is triadic: African/Asian, European, and "New World." This third position looks back at the contradictions of racial definitions of the mixed-blood self

${ }^{1}$ The essay appears in Comparative American Identities: Race, Sex, and Nationality in the Modern Text, ed. Hortense J. Spillers (New York: Routledge, 1991), 40-61. 
as fundamentally black, oppositional stances within colonial educational systems and new letters and liberation movements by commenting on these phenomena in an environment of continuous change. Henry Louis Gates, Jr.'s, successive explications of the Signifying Monkey trope as a hermeneutics of black criticism is a fine example of a fresh approach to comparative literary studies. Gates's interpretations of Their Eyes Were Watching God, Mumbo Jumbo, and The Color Purple establish contextual and textual relationships beyond binaries among works published over a span of forty-five years by Zora Neale Hurston, Ishmael Reed, and Alice Walker. ${ }^{2}$

The representation of contemporary literary history has assumed a binary, often false, division according to gender. Particularly in African diaspora literary studies, the male (canon) precedes and the women writers follow, as though the two discourses were mutually exclusive. Histories of the New Negro, Indigenist, and Negritude movements of the 1920 and 1930 often portray the period as a male phenomenon of racial consciousness and artistic renewal among writers such as Langston Hughes, Claude McKay, Jacques Roumain, Nicolas Guillén, Léon Damas, Aimé Césaire, and Léopold Senghor. Following a similar paradigm, studies of Caribbean literary history-no matter the languagehave separated texts according to a gender-based scheme, or what Roger Abrahams describes as the expressive division between house/ yard and road. ${ }^{3}$ In other words, we encounter two traditions by women and men that do not seem to merge.

Even as the predominantly male new letters voices of the renaissance materialized in the Caribbean, women novelists such as Suzanne Lacascade and Annie Desroy redefined the male narrative and discursive strategies, inaugurating "la littérature féminine" in the Guadeloupe and Haiti of the 1920 and 1930 . Scholars overlooked these early texts primarily because none of the authors participated in either the Indigenist or the Negritude movements. For over five decades a separate tradition developed, unrecognized as such until Maryse Condé published her study of Antillean novelists, La parole des femmes (1979). ${ }^{4}$

\footnotetext{
${ }^{2}$ Henry Louis Gates, Jr., The Signifying Monkey (New York: Oxford University Press, 1988).

${ }^{3}$ Roger Abrahams, The Man-of-Words in the West Indies: Performance and the Emergence of Creole Culture (Baltimore: Johns Hopkins University Press, 1983). Scholarship devoted to new letters is extensive. For bibliographical references, see Nathan Huggins, Harlem Renaissance (New York: Oxford University Press, 1974); Margaret Perry, Harlem Renaissance: An Annotated Bibliography (New York: Garland Publishing, 1982); Victor A. Kramer, Harlem Renaissance Re-Examined (New York: AMS Press, 1987); Colette V. Michael, Negritude: An Annotated Bibliography (West Cornwall, Conn.: Locust Hill Press, 1988).

${ }^{4}$ Maryse Condé, La parole des femmes (Paris: L'Harmattan, 1979).
} 
Binaries are barriers to learning, whether the obstacles preventing communication are demographic, socioeconomic, or linguistic. Binary oppositions in the Caribbean mark the borders of power relationships: low/high land; low/high culture; low/high languages. In the last case, rather than embrace New World Creole discourses, authors from the region must confront the long-held value of writing in a metropolitan language and style. ${ }^{5}$

Binary oppositions also inform feminist practice. During the 1980 s and 1990s scholarship became a terrain of ten unsupportive of the wider sociopolitical activism of living writers. Although the historiography of feminist interventions has assumed various stances since the Women's Liberation movement, many scholars of my generation view feminist practice as synonymous with research and publishing-what we do outside the college classroom on our own, usually subsidized, time. Others commit themselves to service benefiting women in general, whether through venues such as on-campus women's centers, editorial boards of journals, and centers for the study of women or committees such as the Modern Language Association's Committee on the Status of Women in the Profession. Essentially, however, all of these endeavors serve an already established network of scholars, whether on or off the tenured track. I would like to suggest another definition of feminist practice in the 1990 which combines scholarship, service to the field, and political action against the contentious intellectual and political climates in which women produce both primary and secondary texts. In my own experience I have noticed a pattern of alternative intervention which, if we acknowledge the binary opposites that maintain stasis and prevent social change, replicates the search for a third principle, or what Haitian peasants understand as marasa.

When we support living authors such as Rigoberta Menchú, the Quiché activist from Guatemala, recipient of the Nobel Peace Prize in 1992, or the African American choreographer Katherine Dunham, we enter into a liminal space of activism which they have previously occupied in their works. We engage in solidarity with the texts of their lives. Conceptually we promote feminist practice beyond the boundaries of the academy, often subversively, given the regulation of academic freedom within universities. Such regulatory policies are designed, and rightly so, to restrict political agency within the classroom or the use of the mails (and I assume fax machines) for political purposes. Those

${ }^{5}$ The tradition of writing in metropolitan languages as a form of "collective bovarysm" is examined in Jean Price-Mars, Ainsi parla l'oncle (Paris: Imprimerie de Compiègne, 1928) and the counter Creole ideology defended in Jean Bernabé et al., Éloge de la créolité (Paris: Gallimard, 1989). 
of us who brought Rigoberta Menchú to Tufts University in conjunction with her testimony at the United Nations concerning the abuse and torture of Indian activists supported through her honorarium the likelihood that these funds would contribute to direct political action in Guatemala. The organizers of her visit understood the need to serve beyond the binary boundaries of Menchú's existence, namely altiplano (mountain villages) versus finca (plantations), thereby assisting activists to forge another path-the resistance efforts in towns and villages promoted by nameless Quiché peasants and their supporters. Those of us who had read I, Rigoberta Menchú (1983) felt that we knew the author, her family, and the situation she described so painfully in the text. ${ }^{6}$ For two hours she responded to innumerable questions about her published oral history and current events in Guatemala. The exchange confirmed our belief in a testimony akin to the slave narratives historically disparaged by readers unwilling to believe the atrocities revealed in the text. Menchú's appearance has led me to teach the text differently; I now expect disbelief, even suspicion of the text's veracity, and chart these responses among Menchú's implied international readership. In this particular case, practice has informed pedagogy at a much deeper level than the text alone might have done.

Testimony as a speech act contains its own limitations. For readers who have never known peasants anywhere in the world, eye contact becomes crucial. They need to see Rigoberta Menchú, the down-anddirty realities of cane fields, the intrusion of the military. Beyond the dialogics of belief/disbelief, I have found that another territory of reference emerges in screenings of the film When the Mountains Tremble, in which Menchú appears. This filmic testimony helps students to visualize the contexts of oppression out of which Rigoberta Menchús person, commitment, and the text operate.

Similarly, I "met" Katherine Dunham through one of her texts, Journey to Accompong, when I was teaching a course, "Folk Cultures of the New World," in the African American Studies Department at the University of California, Berkeley. Later in 1976 she accepted a residency on campus as a visiting professor. I subsequently served for seven summers as her archivist in East St. Louis. Nearly a decade later, President Jean-Bertrand Aristide's daring attempts to establish democratic rule in Haiti renewed Dunham's commitment to Haitian resistance, reflecting her earlier support of President Dumarsais Estimé in 1947.

Dunham's case exemplifies how feminist practice passed from gen-

${ }^{6}$ I, Rigoberta Menchú: An Indian Woman in Guatemala, ed. Elisabeth Burgos-Debray, trans. Ann Wright (London: Verso, 1984). 
eration to generation can intervene as an alternative strategy of response to a crisis constructed within unyielding binary oppositions. Katherine Dunham, author, scholar, choreographer, and activist, began a hunger strike in February 1992 to protest the continuing deportation of Haitian refugees. A three-week fast sent Dunham, at age eighty-two, in and out of consciousness. ${ }^{7}$ An arena of silence entrapped her cause: the Bush administration refused to acknowledge either her own letter to the president or the flood of telegrams that supported Dunham's drastic measures. Subsequently, the media seriously addressed the political environment surrounding the issues of deportation and repression in Haiti, undoubtedly owing to the earlier responses from the wider community, as well as a series of petitions initiated by activist scholars in African American studies at the University of California and in the Los Angeles community. As in the Anita Hill support network (African American Women in Defense of Ourselves), we petitioned throughout the country basically to save the life of a woman who had opened to many of us the fields of Caribbean and African culture during the 1930 and 1940s, whose dance companies toured fifty-two countries for twenty-five years, and who has received highest honors, including the légion d'honneur in Haiti and the Schweitzer and Kennedy Center awards. As of this writing she continues to live and work in East St. Louis, Illinois, where she was hospitalized for a month. Katherine Dunham was caught in an opposition between the plight of Haitian refugees and the policies endorsed by the Bush administration. The petitions circulated nationwide and internationally sought to establish a road between. ${ }^{8}$

One final example of feminist practice concerns graduate students at the university. As elsewhere, students devoted to African, African American, or Caribbean studies find themselves operating dually and in isolation. Bound to their departments (English, Comparative Literature, Geography, Anthropology), they work against isolation by organizing informal study groups. In 1992, through the African American Studies Department at U.C. Berkeley, the St. Clair Drake Cultural Studies Forum was initiated as a means to open up an institutional space for interdisciplinary studies, at once supporting graduate students' research and establishing a community of scholars willing to listen, learn, and provide models for presenting ideas. ${ }^{9}$ Two assistant professors, Sai-

${ }^{7}$ Dunham ended the hunger strike after forty-seven days in March 1992.

${ }^{8}$ The petition was composed by Margaret Preacely of Los Angeles during the evening of February 20, 1992, and subsequently sent to over fifty individuals, who circulated the document in churches, among Haitian-American citizens, academics who support the antideportation efforts, and others who revere Katherine Dunham and her work.

${ }^{9}$ The forum was named for St. Clair Drake, a specialist in social anthropology, who, 
diya Hartman and Ula Taylor, and I coordinated this endeavor in feminist practice, intending to provide a landscape, figuratively, for students across the disciplines to negotiate between departmental affiliations and informal study groups under the aegis of Cultural Studies. ${ }^{10}$

For me, the fit between marasa theory and practice occurs in intellectual exchanges within the classroom. For the remainder of this essay I refer to examples of feminist pedagogy in my course "Marasa: Caribbean Literature by Women." The syllabus sets up dyads among texts by women authors with the expressed intention of exploring and transforming these binaries. Nonetheless, we approach each text on its own merits in interactive discussions before the students write comparatively about the paired or twinned works. The writing in this course progresses from a series of old-style comparisons of two texts to an exam which requires students to apply the marasa theory in evaluating at least three works. Throughout the fifteen-week course, the potential for marasa analysis accumulates from text to text long before the endterm exam occurs. At Berkeley the students, representing a range of disciplines from biology and English to French and sociology, responded to theory with startling originality.

Marasa is a mythical theory of textual relationships based on the Haitian Vodoun sign for the Divine Twins, the marasa. During the research for my dissertation on Haitian folk performance and popular theater, I became interested in the etymologies of certain widely used terms in Haitian folklore, such as coumbite and marasa. ${ }^{11}$ In the case of marasa, I traced the term back to ancient Dahomey (present-day Benin) in West Africa, to creation myths among the Fon and Ewe. Marasa is a New World deformation of Mawu-Lisa-the female and male gods deriving from the distant but ultimate Creator, Nanabuluku. Mawu-Lisa, according to Fon and Ewe belief systems, generated among others a

like Dunham, was trained at the University of Chicago. In the 1970s Drake volunteered for a year's time to participate in a reading group among black graduate students at Berkeley which he ultimately led. On a monthly schedule we read and analyzed texts such as The Black Jacobins by C. L. R. James and in essence sat at the feet of one our master scholars and teachers.

${ }^{10}$ The forum is open to graduate students and faculty working in African, African American, or Caribbean studies. When I characterize the forum as an example of feminist practice, I refer to origins rather than content. During the fall semester of 1991, a number of graduate students who had sought to sit in my undergraduate course in African American studies, "Marasa: Caribbean Literature by Women," agreed to participate in a group independent study once a week. These women represented a range of disciplines, including anthropology, English, ethnic studies, folklore, and French. The diversity of their training and interests prompted me to create the forum during the spring of 1992.

${ }^{11}$ VèVè A. Clark, "Fieldhands to Stagehands in Haiti: The Measure of Tradition in Haitian Popular Theatre"' (Ph.D. diss., University of California, Berkeley, 1983). 
youngest son, Legba, god of fertility and of the crossroads, the chief linguist, who populated the earth. Mawu-Lisa stand at the interstices between divine and human formations of meaning and participate in both. As a feminist I was drawn to these West African myths because of the central role Mawu, a female spirit, performs in concepts of genesis.

The Haitian sign for the marasa (appended to the syllabus) plays on uniformity and diversity. I have used this visual tension in my pedagogical approach to writing by Caribbean women from the anglophone, creolophone, francophone, hispanophone, and lusophone regions of the Americas. During the first days of class I invite students to read the marasa sign as an intellectual passageway into peasant ways of ordering their largely agrarian realities, a passageway that derives from memories of enslavement and the monocrop culture of plantation economies. The theory is thus based on the peasantry; whether this specific figure drawn from Haitian Creole lore will prove relevant across language and socioeconomic boundaries remains a theoretical tension which we as readers address throughout the course. At this point in my teaching the tension seems more imagined than real, given the common denominator of any number of texts which I have presented over the years. No matter the choices, no matter the historical distance, these texts share memories of plantation economies, cultures, and languages.

Creolization as a process of acculturation and imitation in the Caribbean defines the $1+1=3$ paradigm I proposed earlier. ${ }^{12}$ Diversity is a patterned response to combined European and African cultural practices in the New World: to the struggle to survive in a climate rendered hostile by the search for gold (viz. Columbus), to new illnesses which affected Native Indians, Europeans, and Africans differently throughout the sixteenth through the eighteenth centuries, to plantation labor brutal in theory and practice, and finally to colonial education systems imported from the metropole, which engendered forgetfulness among the colonized, ultimately deforming indigenous cultures and the minds of individuals banished to the subjugated categories of humanity. When we theorize diversity in Caribbean life, lore, and literature, we operate on three interconnected planes of articulation which converge in the specifics of Creole culture and language. Beyond the binaries of European and African, European and Native Indian, European Continental and Latin American, Asian and Caribbean, we find that Caribbean cultures and their authors have created sites of difference

\footnotetext{
${ }^{12}$ Edward Brathwaite, The Development of Creole Society in Jamaica, 1770-1820 (Oxford: Clarendon, 1971).
} 
which challenge our deconstructive notions of the flexible fields of literary theory, practice, and perhaps pedagogy as well.

"Marasa: Caribbean Literature by Women" evolved out of a workshop in American Studies at Tufts University sponsored by the National Endowment for The Humanities. In retrospect, one of the participants-the sociologist Susan Ostrander-described our goals thus: "The aim of that workshop was to develop a set of interdisciplinary courses focused on issues of gender that would be crosslisted with home departments and American Studies."13 The six scholars represented the fields of anthropology, child study, English, psychology, francophone literature, and sociology. I taught the marasa course for three semesters at Tufts before offering a revised version in 1991 for African American Studies at Berkeley.

For a number of reasons, my experiences in teaching the course at Berkeley have been the most successful yet. First of all, as I mentioned earlier, my African American studies courses attract a variety of students, including majors in the humanities, social sciences, and sciences, as well as reentry students, some of whom are close to my age. At Berkeley, seven male students enrolled in a class of thirty-one, almost double the number at Tufts. As is typical of Berkeley, the class was truly multicultural, with many African American students, students from multiracial backgrounds, foreign students (from Japan, from Canada by way of Zambia), Asians, Chicana/os, Hispanics, one lone white male, and one lone Jamaican woman. Because of the makeup of the class, diversity was an issue that students were eager to discuss. Additionally, recent translations into English allowed me to pair works more effectively. Moreover, the Berkeley appointment in African American studies enabled me to concentrate on the African diaspora and to roam intellectually among the various language areas defining Caribbean expression, free from my former duties in Romance languages at Tufts, where I taught French conversation and composition, as well as introductions to French literature. The twinning of narratives which I constructed sought to engage students in considering diversity at several levels: according to genre (Hodge/Edgell); to socioeconomic class (Rhys/Ferré and De Jesus/Menchú); and to feminist themes such as mothering, madness, and healing (Schwarz-Bart/Marshall).

Before we actually discussed the major texts, we played with the marasa concept in short stories or excerpts collected in the Pamela Mordecai-Elizabeth Wilson anthology Her True-True Name (1989), the title

\footnotetext{
${ }^{13}$ The quotation is from a memo by Susan Ostrander inviting prospective members to join the 1990 workshop.
} 
of which derives from Merle Hodge's Crick Crack, Monkey (1970), the first full text we read. With Zee Edgell's Beka Lamb (1982), I intended to represent the female novel of formation from the different perspectives of colonial education systems in Trinidad and Belize. With these two works and others on the reading list, through interactive teaching methods, I hoped to draw students to new readings of the texts beyond the facile binary evaluations which, despite significant exceptions, prevail in the critical literature. ${ }^{14}$ In their thinking and writing, students tackled one or several areas: themes, characterizations, structure, narrative technique, and language. As the semester progressed, the majority ventured beyond purely thematic analyses-an often frightening terrain for nonliterature majors. For the remainder of this essay I will highlight some of the more revealing close readings that emerged within marasa literary practice, and conclude by describing ways in which the students read beyond the twinning relationships which the course design preestablished.

Hodge's Crick Crack, Monkey was a wonderful opening for the course because the text is oppositional in theme, characterizations, structure, narrative technique, and language. Essentially, Hodge represents opposed class differences defined as "ordinaryness" and respectability through the protagonist's aunts, Tantie and Aunt Beatrice. In the opening pages of the narrative, the protagonist, Tee, and her brother are orphaned. When their widowed father departs abruptly from Trinidad for England after his wife's funeral, the children are left in a workingclass family with a single head of household, riotous Tantie, whose vulgar speech in Creole, working-class wit, and determination dominate the first twelve chapters of the narrative. ${ }^{15}$

Most criticism of the novel focuses on the opposition between the two worlds of Tantie and Beatrice-the bourgeois city dweller and relative to whom Tee is sent for continued education beyond the local primary schools. Using the Caribbean culture's symbolic landscapeshouse/yard as sites of expression suggesting women's domains and

\footnotetext{
${ }^{14}$ The exceptions to which I refer are Simon Gikandi, "Narration in the Post-Colonial Moment: Merle Hodge's Crick Crack, Monkey," in Past the Last Post: Theorizing PostColonialism and Post-Modernism, ed. Ian Adam and Helen Tiffin (Calgary: University of Calgary Press, 1990), 13-22, and Rhonda Cobham's translated essay, "Revisioning our Kumblas: Challenges to Feminist and Nationalist Agendas in the Work of Three Caribbean Women Writers," originally published in German in Entwicklungen im Karibischen Raum, 1960-1985, ed. Wolfgang Binder (Erlangen: Universitätsverbund ErlangenNürnberg, 1985), 193-210.

${ }^{15}$ Before we approach the text, students learn to hear and read Creole speech by listening to recordings of the poet Paul Keens-Douglas's work, particularly "Tanti Merle and di fire." This piece works well because Tanti Merle's persona so resembles the character Tantie in Crick Crack, Monkey.
} 
respectability, as opposed to the road/bridge areas of unbridled male behavior-we examined how these paradigms existed in the narrative, discovering how Hodge expands the landscape of affiliations described in Roger Abrahams's Man-of-Words in the West Indies (1983) by including the bush or the mountain refuges of former maroons as part of Tee's legacy. ${ }^{16}$ This is the place to which Tee returns for the summer months, to her grandmother $\mathrm{Ma}$, to traditions of storytelling (thus the title of the novel), and to a fading memory, what Zee Edgell's characters refer to as "befo' time." Deliberately devoting brief space to memories of Tee's summer home Pointe d'Espoir, in chapter 4, Hodge suggests that there is no possible return to communal identity for Tee, even though she resembles her great-great grandmother, called Euphemia by the countryfolk (a process of renaming which occurs as well in Simone Schwarz-Bart's Bridge of Beyond). The nickname has replaced Euphemia's "true-true" name, which Ma has trouble remembering: "[Ma] couldn't remember her grandmother's true-true name. But Tee was growing into her grandmother again, her spirit was in me. They'd never bent down her spirit and she would come back and come back and come back: if only she could live to see Tee grow into her tall proud straight grandmother." ${ }^{17}$ Nonetheless, references to Pointe d'Espoir, and to the world of Tantie's adopted son Mikey, where unemployed men signify on one another at the bridge, open the narrative to levels of expressive behavior not confined to the glorious and rowdy Creole speech of Tantie or to the repressed anglophile domesticity surrounding Aunt Beatrice. Marasa consciousness encourages readers to appreciate a wider range of expression beyond the obvious binary oppositions in the narrative.

Another example of triadic writing surfaces in Jean Rhys's Wide Sargasso Sea (1966), which I paired in the course with Rosario Ferré's collection of short stories, The Youngest Doll (1976). As a unit these narratives portray indolence and madness among upper-class women in Dominica and Puerto Rico, but more important, they draw the reader into issues of narratology, style, and intertextuality, particularly as Wide Sargasso Sea revises Charlotte Brontë's Jane Eyre and the topos of the madwoman in the attic on which contemporary feminist thought has concentrated. ${ }^{18}$ In brief, Wide Sargasso Sea demonstrates conflict at the very level of narrative technique. The novel's three divisions embody divergent perspectives. In part one the child Antoinette reports on changes in her 1830 s colonial world as the emancipation of slaves trag-

\footnotetext{
${ }^{16}$ Abrahams, Man-of-Words.

${ }^{17}$ Merle Hodge, Crick Crack, Monkey (London: Heinemann, 1981).

${ }^{18}$ Sandra Gilbert and Susan Gubar, The Madwoman in the Attic: The Woman Writer and the Nineteenth-Century Literary Imagination (New Haven: Yale University Press, 1979).
} 
ically disrupts her béké (planter class) environment. The adult Antoinette, of part two, married by convenience to Rochester from Jane Eyre, is then seen through his eyes and defined by his voice, uncomfortable, even paranoid, as he lives in a tropical climate new to him with a bride and black household staff he considers insane-a legacy of madness Rhys attributes to the protagonist's mother, Annette. In the final segment, Rochester has transformed Antoinette into "Bertha," and the narrative technique here replicates madness.

Rhys's design in the novel begins with oppositions according to political and socioeconomic difference, gendered perceptions, responses to climate, and language. In the final segment the text confuses point of view intentionally in order to describe the displacement to Britain of a woman whose world is problematically Caribbean-problematic because the central figures over two generations, Annette and Antoinette, rely on a process of creolization through which they participate in black cultural practices such as obeah to alter their situations. Annette is to the servant Christophine as Antoinette is to her playmate Tia, women served and abandoned. In the final section, set in Rochester's mansion, Rhys defines madness in the Caribbean as both cultural and psychological; the ethereal narrative voice constantly changes. There is no center for Antoinette/Bertha Cosway in England, a cautionary tale for the many anglophone Caribbean writers who end their narratives on a note of expectancy: of a better life for colonized subjects in the metropolis. More important, the text invites readers to confront Creole madness from the inside outward, to share Antoinette's confusion, and to enter into "her own where." In other words, Rhys charts a landscape beyond the construct of sanity/madness referenced specifically to women of the béké, the dominant Caribbean minority enslaved by the Edward Rochesters within plantation America, themselves disinherited and disoriented in a New World colored environment. ${ }^{19}$ Essentially, chapter 3 of Wide Sargasso Sea describes the deep-sea spaces of alienation which confine Antoinette/Bertha physically and psychically. Experiencing a negative epistemic break from the flamboyant tropical gardens in the Caribbean of chapters 1 and 2, she is displaced to the gray climate and manicured English gardens that define Jane and Rochester's existence at Thornfield..$^{20}$

\footnotetext{
${ }^{19}$ See June Jordan's novel in black English, His Own Where (New York: Crowell, 1970); Mary Lou Emery, Jean Rhys at "World's End": Novels of Colonial and Sexual Exile (Austin: University of Texas Press, 1990); Angelita Reyes, "Christophine, Nanny, and Creole Difference: Reconsidering Jean Rhys's West Indian Landscape and Wide Sargasso Sea," in The Road to Guinea: Essays in Black Comparative Literature, ed. Edward Ako (London: Heinemann, 1992).

${ }^{20}$ On positive versions of epistemological breaks, consult Sylvia Wynters, "The Ceremony Must Be Found: After Humanism," Boundary 2 12.3-13.1 (Spring-Fall 1984): 19-70.
} 
Similar rereadings occurred in our discussions of Child of the Dark (1960) by a homeless woman living in the favelas of Brazil, in I, Rigoberta Menchú, an oral history of the Quiché activist recorded and edited by the Venezuelan anthropologist Elisabeth Burgos-Debray, and in the pairing of Schwarz-Bart's Bridge of Beyond (1972) with Paule Marshall's Praisesong for the Widow (1983). In facilitating discussion I was aware in advance of the potential for revealing interactions in class, given the many times I have approached these texts from a marasa perspective. This time, however, I was amazed at the connections the students made during the exam on the basis of brief quotations I provided in advance from three sources: Laura Neisen de Abruña on bonding, Shoshana Felman on writing and madness, and bell hooks on confession and memory as expressive skills for talking back. ${ }^{21}$

The exams were a delight to read. One student compared nature, community, memory, and ceremony in The Bridge of Beyond, I, Rigoberta Menchú, and Praisesong for the Widow. Another dealt with the wake as a site of memory in Beka Lamb, Praisesong, The Youngest Doll, and I, Rigoberta Menchú. In the texts by Hodge, Menchú, and Marshall, another student examined the establishment of critical perspectives on the self. Lisa Ze, a junior, used the Felman quotation to associate madness and the style of narration in the texts by Marshall, Schwarz-Bart, and Menchú. Ze returned to the marasa principle in her senior honors thesis, "Crazy Quilt: Movement of the Mulatta in Literary and Personal Discourse," a comparative analysis of theme and narrative technique in texts by Nella Larsen, Michelle Cliff, and Bessie Head-women writing about mixed-race issues over time throughout the African diaspora in the United States, Jamaica, and South Africa. Continuing a pedagogical approach established after the first writing assignment, the week following the exam I asked students to share their subjects orally with their peers. Generally these sessions when readers respond to the paired texts are predictable. Here, however, I was astounded by the connections the students had made over the fifteen weeks-a relatively short time to expect such depths of analysis. I can only attribute their prix des yeux (a concept defining the third and highest stage of learning in Haitian Vodoun) to the theoretical framework of the course. In this particular class, marasa served as a more creative theoretical concept than I had ever imagined.

${ }^{21}$ Laura Niesen de Abruña, "Twentieth-Century Women Writers from the EnglishSpeaking Caribbean," in Caribbean Women Writers, ed. Selwyn R. Cudjoe (Wellesley, Mass.: Calaloux Publications, 1990), 90; Shoshana Felman, Writing and Madness (Ithaca: Cornell University Press, 1985), 17, 19; bell hooks, Talking Back: Thinking Feminist, Thinking Black (Boston: South End Press, 1988), 109-10. 
The next generation of this course offered at the graduate level might well compare the ways in which narratives speak to one another beyond gender distinctions. Moving beyond new letters and the construction of Caribbean literary history would, obviously, include the foregoing but would also draw readers to areas of discourse, structure, and genre that represent another principle of interpretation or marasa. Holding close to the ground of plantation economies, such a course would examine paradox, cyclicity, repetition, and the bildungsroman in writings by Caribbean women and men, ultimately compelling us as critics to assume another, comparative approach to the dialectic of displacement. 